\title{
Estimation of the Impact of the New International Land and Sea Trade Channel on the Development of the Trade Potential of 8 Domestic Provinces and Cities
}

\author{
Gu Jijian ${ }^{1}$, Feng Lipeng ${ }^{2 *}$, He Liyan ${ }^{2}$, Zhong Heng $^{2}$ \\ ${ }^{1}$ Chongqing Vocational College of Transportation, Chongqing Jiangiin 402247 \\ ${ }^{2}$ Chongqing University of Arts and Science, Chongqing Yongchuan 402160
}

\begin{abstract}
The new international land and sea trade channel is an important part of China's "The Belt and Road Initiative" going south, with Chongqing as the operating center, and 7 provinces and cities such as Guangxi, Guizhou, and Gansu as key nodes. Gravity Model of Trade is adopted to analyze the issue of trade creation effect and trade transfer effect in the flow of China-ASEAN trade in detail. According to the theoretical trade value calculated by the export gravity model, the actual trade value was divided by the theoretical value to calculate the trade potential coefficient, which has been applied to measure the trade potential of export of 8 provinces and cities to the ten ASEAN countries. It is concluded that trading partners are in different types ranging from "potential remodeling", "potential expansion" to "great potential", and heterogeneity tests are performed to prove the self-consistency of the effect measurement. Further, it is proposed that to further develop trade relations, we must develop positive factors to promote export trade, stimulate trade needs of partner countries, and actively develop trade market countermeasures.
\end{abstract}

\section{INTRODUCTION}

On November 12, 2018, the "Southbound Channel" of China-Singapore interconnectivity was officially renamed as "New Channel for International Land and Sea Trade", which means that the geographical scope and direction of the interconnection construction are broader, and it is expected to be linked with the "Belt and Road" initiative, which is expected to further promote the long-term expansion and radiation of the Sino-Singapore (Chongqing) project. On January 7, 2019, eight provinces, autonomous regions, and municipalities, Chongqing, Guangxi, Guizhou, Gansu, Qinghai, Xinjiang, Yunnan, and Ningxia signed a framework agreement to jointly establish a "Land and Sea New Channel". A quantitative analysis of the trade conditions of the eight provinces from 2008 to 2017 promoted by the "Land and Sea New Channel" is conducted, and recommendations on the calculation results of the impact effects of the trade development of the eight provinces and cities is proposed in the thesis.

\section{Modeling and Measurement Methods}

\subsection{Model Introduction}

The gravity model is a powerful tool for empirical research in international trade. The general form of the gravity model is $X_{i j}=A Y_{i} Y_{j} / D_{i j}$, in which $X_{i j}$ indicates the amount of trade between $i$ country and $j$ country, that is, the $i$ country's exports to the $j$ country, $Y_{i}$, $Y_{j}$ indicate $i$ country and $j$ country's GDP separately, and $D_{i j}$ indicates the distance between $i$ country and $j$ country. The classic gravity model holds that the scale of bilateral trade is proportional to the total economic volume, and inversely proportional to the distance between the two countries. Since then, many scholars have also introduced variables such as population, per capita income, and exchange rate. This article uses the China-ASEAN Free Trade Area as the background. In 2017, the implementation of the new international land and sea trade channel is an opportunity to study whether the implementation of the new land and sea trade channel will promote bilateral trade. The main study is the impact of the opening of the new land and 
sea channel on the trade between the 8 provinces and cities that signed the framework agreement and ASEAN.

\subsection{Model Settings}

Pairing the general form of the gravity model is a relatively common method in international trade, and it is easier to conduct empirical analysis using linear regression. The processed gravitational model form:

$$
\ln X_{i j}=c+\alpha \ln \left(Y_{i} Y_{j}\right)-\beta \ln \left(D_{i j}\right)-\varepsilon
$$

$c$ is a constant term and $\varepsilon$ is an error, the classic trade gravity model can draw the relationship between trade, the economy and distance between the two countries according to the above formula. Many scholars use the gravity model for empirical analysis, adding variables such as GDP product, trade dependence, whether the two countries border, and language differences. This article first considers 8 new population sizes, country area, land borders, differences in per capita GDP, trade dependence, and consumer price index based on the distance and GDP used as explanatory variables in the classic gravity model. Variables for model interpretation. However, in view of the nature of the variables and the interaction between the variables, in fact, some variables have a strong correlation, such as the difference between population size and GDP, per capita GDP, and between GDP and the consumer price index. From the perspective of scientific measurement methods, if there is a strong correlation between explanatory variables, the model regression results obtained will lack a certain explanatory ability. In order to verify this situation, all candidate explanatory variables were substituted into the model's preliminary regression analysis. The results show that if all explanatory variables are included in the model analysis, the significance of each variable is weakened, and the goodness of fit of the model as a whole is also reduced. Weakened. Therefore, in order to reduce the degree of colinearity between variables, the explanatory variables with strong correlation are reduced, and the most significant explanatory variables are retained to ensure that the model's goodness of fit value is within the credible range, thereby improving the reliability of the model as a whole. degree. Therefore, combined with the research background, this paper's gravity model finally uses five gross domestic product $\left({ }^{G D P_{j}}\right)$, the difference between per capita gross domestic product ( $\left.G D P_{i}-G D P_{j}\right)$, the straight line distance between the two regions, the degree of trade dependence $\left({ }^{O P E N_{j}}\right)$, and the consumer price index $\left({ }^{C P I_{j}}\right)$. Explanatory variable analysis.

Variable $G D P_{j}$ is used because the economic level of a country is the driving force of bilateral trade. The more developed the economy, the more prominent the trade potential. GDP can be used as an indicator of the country's import and export level. The introduction of variable $G D P_{i}-G D P_{j}$ is based on Linde's income hypothesis. The smaller the income gap between the two countries, the closer the supply and demand structure of the two countries is. The larger the trade volume, the smaller the converse. Trade dependence represents the degree of economic openness and represents the ratio of a country's import and export volume to that country's GDP during a particular period. The higher the degree of trade dependence, the smaller the trade barriers. The consumer price index reflects the degree of inflation or deflation in a country. The consumer price index rises, a country's imports increase, and its exports decrease.

Table 1 Variable description

\begin{tabular}{|c|c|c|}
\hline variable & $\begin{array}{l}\text { Anticipation } \\
\text { symbol }\end{array}$ & meaning \\
\hline$E X I T_{i j t}$ & & $i$ Region exports to $j$ country (ten thousand US dollars) \\
\hline$I M P O R T_{i j t}$ & & $i$ Region import from $j$ country (ten thousand US dollars) \\
\hline$G D P_{j t}$ & + & $j$ Country's gross domestic product (ten thousand US dollars) \\
\hline$D I F F G D P_{i j t}$ & - & $\begin{array}{c}i \text { Region and } j \text { Country's GDP per capita difference (US } \\
\$ 10,000)\end{array}$ \\
\hline$D I S_{i j}$ & - & Distance from $i$ region to $j$ country $(\mathrm{km})$ \\
\hline$O P E N_{j t}$ & + & Foreign trade dependence $(\%)$ \\
\hline$C P I_{j t}$ & + & Consumer price index $(\%)$ \\
\hline$D 1$ & + & $\begin{array}{l}\text { Describe the dummy variable created by trade (take } 1 \text { if the } j \\
\text { country is a member country, otherwise take } 0 \text { ) }\end{array}$ \\
\hline$D 2$ & - & $\begin{array}{l}\text { Dummy variable describing trade transfer (take } 1 \text { if the } j \text { country is } \\
\text { a non-member, otherwise } 0 \text { ) }\end{array}$ \\
\hline
\end{tabular}


Note: The China-ASEAN Free Trade Area was officially launched in January 2010. The dummy variables are 0 in 2008 and 2009. The remaining values are determined by the above constraints. At the same time, the implementation year of the new international land and sea trade channel is set to 1 .

\subsection{Sample Selection}

Since the Middle East Free Trade Zone was officially launched on January 1, 2010, considering the impact of related factors on trade effects before and after the completion of the Free Trade Zone, this study selects sample data from 2008. The new land and sea channel officially started operation in 2017. In order to ensure the integrity of the data and the consistency of the statistical caliber; this study selected 8 provinces and cities (Chongqing, Guangxi, Guizhou, Yunnan, Xinjiang, Ningxia, Qinghai, Gansu) that signed the framework agreement in 2017 and ten ASEAN countries (Indonesia, Malaysia, Philippines, Laos, Myanmar, Brunei, Cambodia, Singapore, Thailand, Vietnam) and ten non-member countries (United States, Canada, Russia, Brazil, Japan, South Korea, India, United Kingdom, France, Germany) to conduct empirical research. And generally speaking, the data of the past ten years can clearly reflect the long-term trend of trade effects after the implementation of the free trade zone. In the process of empirical research, because the trade of individual provinces and cities is not obvious, 8 provinces and cities are considered as a whole to conduct research. The selection of non-member countries is based on the volume of trade with China in recent years. The above ten non-member countries China's trade volume accounts for about $60 \%$ of China's trade volume, and the data are typical and representative.

\subsection{Data Source and Description}

From 2008 to 2017, the import and export trade volume and GDP levels of 8 provinces and cities with ten ASEAN countries and ten non-member countries are from the statistical yearbooks of 8 provinces and cities.
The straight-line distance between the 8 provinces and cities and the ten ASEAN countries and non-member countries comes from the website http://www.timeanddate.com. Due to the research characteristics, the 8 provinces and cities are considered as an overall trade, so the distance needs to be averaged. After the straight-line distance between each province and city and 20 countries is obtained, the average distance between 8 provinces and cities can be used to obtain the average distance between 8 provinces and cities and 20 countries. The GDP level, CPI (with 2010 as the base period), and the population of the 20 countries are derived from the World Bank database. The degree of foreign trade dependence is calculated from the ratio of the total import and export trade of a country to the GDP, of which the import and export trade of 20 countries the total is derived from the United Nations Commodity Trade Database. Logarithmic processing was performed on the above data to eliminate the effect of heteroscedasticity, and Eviews8.0 was used for corresponding panel data analysis.

\subsection{Panel Data Stationarity Test}

The panel data contains two dimensions of time and space. Before analysis, the time series must be stable. Non-stationary time series participating in regression modeling and analysis will cause false regression problems. Therefore, before analyzing the panel data, in order to ensure the validity of the parameter estimation, a unit root test is performed on the main variables. Panel-unit root test using Fisher-ADF to analyze the explanatory variables and the main explanatory variables. If the sequence is a stationary sequence, you can continue modeling; if the sequence is a non-stationary sequence, you need to perform analysis methods such as difference processing.

Table2 Fisher-ADF test of main variables

\begin{tabular}{ccc}
\hline Variable & ADF test statistics & P-value \\
\hline $\ln I M P O R T_{i j t}$ & 37.770 & 0.480 \\
$\ln E X I T_{i j t}$ & 38.804 & 0.524 \\
$\ln G D P_{j t}$ & 54.89 & 0.059 \\
$\ln D I F F G D P_{i j t}$ & 99.884 & 0.000 \\
$\ln O P E N_{j t}$ & 70.448 & 0.002 \\
$\ln C P I_{j t}$ & 67.617 & 0.004 \\
\hline
\end{tabular}

The Fisher-ADF test results show that the null hypothesis of $\ln I M P O R T_{i j t}$ and $\ln E X I T_{i j t}$ cannot be rejected at a significance level of $10 \%$, indicating that the data $\ln I M P O R T_{i j t}$ and $\ln E X I T_{i j t}$ from 2008 to 2017 are non-stationary, and the remaining explanatory variables all rejected the null hypothesis at a significance level of $10 \%$. The data is stable. The above 6 variables are non-homogeneous simple integers. Therefore, we need to use the first-order difference method to process the variables, and then perform the Fisher-ADF test. All variables can reject the null hypothesis at a significance level of 5\%. Variable one-order single whole. 
Table 3 Fisher-ADF test after first order difference

\begin{tabular}{ccc}
\hline Variable & ADF test statistics & P-value \\
\hline $\ln I M P O R T_{i j t}$ & 103.748 & 0.000 \\
$\ln E X I T_{i j t}$ & 101.965 & 0.000 \\
$\ln G D P_{j t}$ & 116.079 & 0.000 \\
$\ln D I F F G D P_{i j t}$ & 68.406 & 0.003 \\
$\ln O P E N_{j t}$ & 128.703 & 0.000 \\
$\ln C P I_{j t}$ & 72.853 & 0.001 \\
\hline
\end{tabular}

\subsection{Panel data Co-integration Inspection}

After the stationarity test, the co-integration test is performed on the variables to observe the long-term equilibrium relationship between the main variables, and the subsequent regression analysis can only be performed after the variables have a long-term equilibrium relationship. The co-integration test methods mainly include Engle-Granger test and Johanson test. The Engle-Granger test is used to perform co-integration analysis between variables. Since imports and exports are to be studied, $\ln I M P O R T_{i j t}$ and $\ln E X I T_{i j t}$ remaining variables are co-integrated for the explanatory variables .

Table 4 Co-integration test of main variables $\left(\ln I M P O R T_{i j t}\right.$ for the explained variable $)$

\begin{tabular}{ccc}
\hline Variable & Residual test statistics & P-value \\
\hline $\ln D I F F G D P_{i j t}$ & -3.642 & 0.000 \\
$\ln G D P_{j t}$ & -3.809 & 0.000 \\
$\ln O P E N_{j t}$ & -2.955 & 0.000 \\
$\ln C P I_{j t}$ & -4.432 & 0.000 \\
\hline
\end{tabular}

Table 5 Co-integration test of main variables ( $\ln E X I T_{i j t}$ for the explained variables)

\begin{tabular}{ccc}
\hline Variable & Residual test statistics & P-value \\
\hline $\ln D I F F G D P_{i j t}$ & -7.679 & 0.000 \\
$\ln G D P_{j t}$ & -4.566 & 0.000 \\
$\ln O P E N_{j t}$ & -7.439 & 0.000 \\
$\ln C P I_{j t}$ & -6.411 & 0.000 \\
\hline
\end{tabular}

In both cases, each variable rejected the null hypothesis with a significance level of $5 \%$. It is believed that there is a co-integration relationship between the explanatory variable and the explanatory variable, that is, there is a long-term equilibrium relationship between the explanatory variable and the explanatory variable. You can use the variable for regression. analysis.

\subsection{Empirical Analysis of Trade Creation Effect}

The import and export volume between the 8 provinces and cities and ASEAN are quite different. Empirical analysis is carried out from the aspects of import and export, and the trade effects between the 8 provinces and cities and ASEAN are examined from the aspects of import and export. According to the basic form of the above gravity model and the selected variables, the following trade gravity model is established.

Trade creates export gravity models

$$
\begin{aligned}
\ln E X I T_{i j t} & =\alpha_{0}+\alpha_{1} \ln G D P_{j t}+\alpha_{2} \ln D I F F G D P_{i j t}+\alpha_{3} \ln D I S_{i j} \\
& +\alpha_{4} \ln O P E N_{j t}+\alpha_{5} \ln C P I_{j t}+\alpha_{6} D 1+\varepsilon_{i t}
\end{aligned}
$$


Trade creates import gravity models: Trade creates import gravity models:

$$
\begin{aligned}
\ln E_{i j t} & =\alpha_{0}+\alpha_{1} \ln G D P_{j t}+\alpha_{2} \ln D_{F F G D P_{i j t}}+\alpha_{3} \ln D I S_{i j} \\
& +\alpha_{4} \ln \text { OPEN }_{j t}+\alpha_{5} \ln C P I_{j t}+\alpha_{6} D 1+\varepsilon_{i t}
\end{aligned}
$$

Where $\quad i=1,2,3 \ldots, 20$

$t=2008,2009, \ldots, 2017 ; \alpha_{0}$ is a constant term, $\alpha_{1}, \alpha_{2}, \ldots$ is a variable coefficient, and $\varepsilon_{i t}$ is an error term. The export gravity model is the same as the dummy variable for the import gravity model, with a value of 0 from 2008 to 2009, a value of 1 from ASEAN member states from 2010 to 2017, and a value of 1 from both member and non-member states in 2017. Coefficients of dummy variables are used to measure trade creation effects. Use Eviews8.0 to perform regression analysis on the panel data of the import and export gravity models. First, use the Hausman test to analyze whether the model uses a random effect model or a fixed effect model. If the Hausman test rejects the null hypothesis at the $5 \%$ confidence level, use the fixed-effect model, if you do not reject the null hypothesis, you need to use a random effect model for analysis.

Export Gravity Model Regression Results:

$$
\begin{aligned}
\ln E X I T_{i j t}= & -10.43+0.901 \ln G D P_{j t}-1.065 \ln D I S_{i j}-0.295 \ln D I F F G D P_{i j t} \\
& +0.960 \ln O P E N_{j t}+14.688 \ln C P I_{j t}+0.710 D 1+\varepsilon_{i t}
\end{aligned}
$$

From the regression results in Table 5 , the $\mathrm{R}$ square is 0.5392 , and the fitting effect is good. The Hausman test does not reject the null hypothesis and use the random effect analysis model results. All variable coefficients are in line with expectations, the variables are highly significant, and the regression results have a high degree of confidence. Specifically, the $j$ country 's GDP level in this return shows that it has a significant boost to the exports of the eight provinces and cities. The higher the $j$ country 's economic level, the more it can promote bilateral trade. For every 1 unit of GDP change in $j$ country, the exports of 8 provinces and cities will increase by 0.901 units. Distance has a strong hindering effect on exports. For each additional unit of distance, the export of 8 provinces and cities will decrease by 1.065 units. The longer the distance, the higher the transportation cost. The two countries will consider the cost factor to reduce trade interactions. Transportation costs is the main factor hindering the development of bilateral trade. The difference in per capita GDP between the 8 provinces and cities and the remaining 20 countries reflects the supply and demand structure of the two regions. The smaller the gap, the larger the bilateral trade volume, and for each unit increase in the per capita GDP difference, the exports of 8 provinces and cities will decrease by 0.295 units. The $j$ country's foreign trade dependence and consumer price index coefficients are all greater than 0 , indicating that both the $j$ country's foreign trade dependence and the consumer price index have a driving effect on the exports of the eight provinces and cities. The exports of the 8 provinces and cities will increase by $0.960 \%$ for every 1 unit increase of The $j$ country's foreign trade dependence; the every one unit increase of $j$ country's consumer price index, the exports from 8 provinces and cities will increase by 14.688 units. The dummy variable coefficient is 0.710 , indicating that when the $j$ country is a member country, 8 provinces and cities will increase exports by 0.710 units. The trade creation effect was reflected, "the construction of the China-ASEAN Free Trade Area is more conducive to China's export trade with ASEAN, which is consistent with the results of the overall data analysis"" ""After the FTA agreement was fully reached in 2010, China 's real import and export trade volume with ASEAN and its fitted import and export trade volume with synthetic ASEAN also showed a positive gap. This shows that the net trade effect of the CAFTA strategy is generally Positive, thus creating the creative effect of China's bilateral import and export trade with ASEAN"2.

Table 6 Regression results of the trade creation export gravity model

\begin{tabular}{ccccc}
\hline Variable & Coefficient & Std. Error & t-Statistic & Prob. \\
\hline$C$ & -10.4333 & 5.1813 & -2.0136 & 0.0454 \\
$\ln G D P_{j t}$ & 0.9010 & 0.1187 & 7.5940 & 0.0000 \\
$\ln D I S_{i j}$ & -1.0647 & 0.3388 & -3.1428 & 0.0019 \\
$\ln D I F F G D P_{i j t}$ & -0.2948 & 0.1260 & -2.3393 & 0.0203 \\
$\ln O P E N_{j t}$ & 0.9598 & 0.2537 & 3.7835 & 0.0002 \\
$\ln C P I_{j t}$ & 14.6882 & 2.5075 & 5.8577 & 0.0000 \\
$D 1$ & 0.7103 & 0.1697 & 4.1846 & 0.0000 \\
\hline
\end{tabular}

Table7 Regression results of the trade creation export gravity model

\begin{tabular}{c|c|c|c}
\hline R-squared & 0.5392 & Mean dependent var & 3.5007 \\
\hline Adjusted R-squared & 0.5249 & S.D. dependent var & 1.0955 \\
\hline
\end{tabular}




\begin{tabular}{c|c|c|c|c}
\hline S.E. of regression & 0.7551 & \multicolumn{2}{|c|}{ Sum squared resid } & 110.0457 \\
\hline F-statistic & 37.6370 & \multicolumn{2}{|c|}{ Durbin-Watson stat } & 0.6194 \\
\hline Prob(F-statistic) & 0.0000 & & & \\
\hline
\end{tabular}

Regression Results of Imported Gravity Model:

$$
\begin{aligned}
\ln I M P O R T_{i j t}= & 280.525+4.107 \ln G D P_{j t}-56.591 \ln D I S_{i j} \\
& -8.258 \ln D I F F G D P_{i j t}+0.339 D 1+\varepsilon_{i t}
\end{aligned}
$$

The trade dependence and consumer price index of $\mathrm{j}$ country is not significant in the import gravity model and is excluded. From the regression results in Table 6 , the $\mathrm{R}$ square of export gravity model is 0.9527 , and the fitting effect is good. Hausman test rejects original hypothesis using fixed effect analysis model results. All variable coefficients are in line with expectations in import gravity model, the variables are highly significant. Specifically, the j country 's GDP level shows that it has a significant boost to the imports of the eight provinces and cities. $\mathrm{j}$ country's GDP for every unit increase, 8 provinces and cities imports will be driven by 4.107 units. Distance is negatively correlated with imports. For each additional unit of distance, the import volume of 8 provinces and cities will be reduced by 56.591 units. The effect of distance on the import obstruction of 8 provinces and cities is very obvious. The difference in GDP per capita has an obstacle to imports, and the greater the difference, the smaller the trade flow between the two countries. For every additional unit increase of GDP difference between 8 provinces and cities and $\mathrm{j}$ country, 8 provinces and cities will be reduced by 8.258 units of imports. The coefficient of the virtual variable $D 1$ is 0.339 , indicating that when the $\mathrm{j}$ country is a member country, the import of 8 provinces and cities will increase by 0.339 units, which is reflected in the trade creation effect on the import of 8 provinces and cities.

Table8 Regression Results of Trade Creation Import Gravity Model

\begin{tabular}{ccccc}
\hline Variable & Coefficient & Std. Error & t-Statistic & Prob. \\
\hline$C$ & 280.525 & 84.542 & 3.318 & 0.001 \\
$\ln G D P_{j t}$ & 4.107 & 0.521 & 7.883 & 0.000 \\
$\ln D I S_{i j}$ & -56.591 & 14.468 & -3.911 & 0.000 \\
$\ln D I F F G D P_{i j t}$ & -8.258 & 1.925 & -4.291 & 0.000 \\
$D 1$ & 0.339 & 0.198 & 1.706 & 0.090 \\
\hline
\end{tabular}

Table9 Regression Results of Trade Creation Import Gravity Model

\begin{tabular}{c|c|c|c}
\hline R-squared & 0.9527 & Mean dependent var & 10.4275 \\
\hline Adjusted R-squared & 0.9465 & S.D. dependent var & 3.2463 \\
\hline S.E. of regression & 0.7507 & Akaike info criterion & 2.3764 \\
\hline Sum squared resid & 99.1728 & Schwarz criterion & 2.7722 \\
\hline Log likelihood & -213.6423 & Hannan-Quinn criter. & 2.5366 \\
\hline F-statistic & 154.1685 & Durbin-Watson stat & 1.0613 \\
\hline Prob(F-statistic) & 0.0000 & & \\
\hline
\end{tabular}

\subsection{Empirical Analysis of Trade Transfer Effect}

Taking the 8 provinces and cities as a whole to study the trade transfer effect of the China-ASEAN Free Trade Area to the 8 domestic provinces and cities, an empirical analysis is still conducted based on the above samples. The gravity model of the trade diversion effect is established as follows:
Gravity model of trade transfer:

$$
\begin{aligned}
& \ln I M P O T_{i j t}= \alpha_{0}+\alpha_{1} \ln G P_{j t}+\alpha_{2} \ln P_{j t}+\alpha_{3} \ln C D_{i t} G D_{j t}+\alpha_{4} \ln D F F G D_{j i t} \\
&+\alpha_{5} \ln D S_{i j}+\alpha_{6} \ln O P E N_{j t}+\alpha_{7} \ln C P_{j t}+\alpha_{8} D 2+\varepsilon_{i t} \\
& i=1,2,3 \ldots, 20 ; t=2008,2009, \ldots, 2017 ; \alpha_{0}
\end{aligned}
$$

is a constant term, $\alpha_{1}, \alpha_{2}, \ldots$ is a variable coefficient, 
and $\varepsilon_{i t}$ is an error term. The dummy variable $D 2$ has a value of 1 for non-member countries from 2008 to 2017 , and is 1 for both member and non-member countries in 2017. The remaining values are 0 . The coefficient of the dummy variable is used to measure trade transfer effects. If the coefficient is positive, it indicates when $j$ country is a non-member country, it still promotes the import trade of 8 provinces and cities, and is not affected by the free trade zone. There is no trade transfer effect; if the coefficient is negative, it indicates that when $j$ country is a non-member country, the imports of the 8 provinces and cities will decrease accordingly, and the trade of the 8 provinces and cities will be transferred to the free trade zone, which will adversely affect world trade.

Regression results of the gravity model of trade transfer:

$$
\begin{aligned}
\left.\ln I M O R\right|_{i j t}= & -14.887-0.0192 \ln C P_{i t} G P_{j t}+1.9023 \ln G P_{j t}-1.9597 \ln D F F O P_{i j t} \\
& -21061 \ln D S_{i j}-0.8091 \ln C P E N_{j t}+6.8133 \ln C H_{j t}+0.7389 D 2+\varepsilon_{i t}
\end{aligned}
$$

The regression results in Table 9 show that the R-squared is 0.953 , and the fitting effect is good. The Hausman test rejects the null hypothesis and uses a fixed effect model to analyze the results. Specifically, in the gravity model of trade transfer, $j$ country's GDP level has promoted the import trade of 8 provinces and cities. For each additional unit increase of GDP in $j$ country, the import value of the 8 provinces and cities will increase by 4.353 units. The distance between the two regions severely restricts the import of the 8 provinces and cities. For each increase in the distance between $j$ country and the 8 provinces and cities, the imports of the 8 provinces and cities will decrease by 61.677 units. The dummy variable coefficient is positive, indicating that the non-member countries will not reduce the import trade of the 8 provinces and cities, and the imports of the 8 provinces and cities have not been affected. The impact of the free trade zone does not have a trade diversion effect.

Table10 Regression results of import gravity model of trade transfer

\begin{tabular}{ccccc}
\hline Variable & Coefficient & Std. Error & t-Statistic & Prob. \\
\hline$C$ & 306.881 & 80.070 & 3.833 & 0.000 \\
$\ln G D P_{j t}$ & 4.353 & 0.448 & 9.719 & 0.000 \\
$\ln D I S_{i j}$ & -61.677 & 13.490 & -4.572 & 0.000 \\
$\ln D I F F G D P_{i j t}$ & -8.941 & 1.787 & -5.004 & 0.000 \\
$D 2$ & 0.525 & 0.265 & 1.984 & 0.049 \\
\hline
\end{tabular}

\begin{tabular}{|c|c|c|c|}
\hline R-squared & 0.953 & Mean dependent var & 10.427 \\
\hline Adjusted R-squared & 0.947 & S.D. dependent var & 3.246 \\
\hline S.E. of regression & 0.749 & Akaike info criterion & 2.371 \\
\hline Sum squared resid & 98.608 & Schwarz criterion & 2.767 \\
\hline Log likelihood & -213.071 & Hannan-Quinn criter. & 2.531 \\
\hline F-statistic & 155.096 & Durbin-Watson stat & 1.081 \\
\hline Prob(F-statistic) & 0.000 & & \\
\hline
\end{tabular}

Table 11 Regression results of import gravity model of trade transfer

Many factors play a role in the trade effect between multiple regions. In addition to the several variables used in the above gravity model, there are likely other potential factors that have a more significant effect on the trade effect. Therefore, the above variables are substituted for trade gravity. After the model is analyzed, further robustness tests are needed to ensure the reliability of the evaluation method and index interpretation ability, while eliminating the possibility of accidentality of the model. This paper conducts a robustness test from the perspective of variables and introduces foreign direct investment (OFDI) variables, The infrastructure investment variables of the 10
ASEAN countries and non-member countries, replaced the foreign trade dependence and consumer price index variables in the original model, and repeated regressions were selected. The reasons for selecting the foreign direct investment and infrastructure construction investment variables of each country to replace is that in recent years, many Chinese enterprises have invested a lot in many industries in ASEAN countries, and foreign investment will definitely have an impact on export trade, so foreign direct investment is likely to be another potential influencing factor of trade effects; meanwhile, the foundation investment in facilities will play a positive role in trade. Infrastructure investment of each 
country determines the trade potential to a certain extent. In summary, the other variables are controlled, and the two variables in the model are replaced. The data processing method and model regression method are the same as the original model, and the regression analysis is performed again. The regression results show that each coefficients and significance of the variables are still the same as the original model, indicating that the original model does not have the problem of contingency, and the original model has a strong convincing interpretation of the trade effect.

Table 12 Potential coefficients of export trade of 8 provinces and cities to ten ASEAN countries from 2008 to 2017

\begin{tabular}{cccccccccccc}
\hline & Year & Year & year & year & \multirow{2}{*}{2012} & year & Year & 2015 & 2016 & 2017 \\
& 2008 & 2009 & 2010 & 2011 & & 2013 & 2014 & year & year & year \\
\hline Indonesia & 0.47 & 0.51 & 1.59 & 1.12 & 0.65 & 0.69 & 0.61 & 0.85 & 0.99 & 0.69 \\
Malaysia & 0.62 & 0.25 & 0.59 & 0.47 & 0.24 & 0.18 & 0.14 & 0.12 & 0.14 & 0.18 \\
Philippines & 0.62 & 0.64 & 1.60 & 1.24 & 1.42 & 1.51 & 1.68 & 1.15 & 0.59 & 0.43 \\
Singapore & 0.36 & 0.33 & 0.86 & 0.64 & 0.41 & 0.27 & 0.20 & 0.13 & 0.11 & 0.11 \\
Thailand & 0.08 & 0.73 & 0.87 & 0.84 & 0.69 & 0.69 & 0.52 & 0.35 & 0.10 & 0.30 \\
Brunei & 13.42 & 15.15 & 13.09 & 3.50 & 0.50 & 0.30 & 0.25 & 0.14 & 0.36 & 2.48 \\
Vietnam & 0.05 & 0.03 & 0.09 & 0.13 & 0.17 & 0.18 & 0.18 & 0.15 & 0.03 & 0.04 \\
Laos & 0.13 & 0.08 & 0.20 & 0.33 & 0.33 & 0.13 & 0.15 & 0.39 & 0.52 & 0.56 \\
Myanmar & 0.06 & 0.04 & 0.44 & 0.14 & 0.15 & 0.12 & 0.13 & 0.18 & 0.18 & 0.24 \\
Cambodia & 0.51 & 0.85 & 1.22 & 0.24 & 0.99 & 0.79 & 1.19 & 0.59 & 1.02 & 1.11 \\
\hline
\end{tabular}

Table 12 lists the trade potential of the 8 provinces and cities to the 10 ASEAN countries from 2008 to 2017.The trade potential coefficients of Malaysia, Vietnam, Laos, and Myanmar were lower than 0.8 from 2008 to 2017, indicating that Malaysia, Vietnam, and Laos For 8 provinces and cities, Myanmar has always been in the role of "huge potential", and greater trade potential has not been tapped. Indonesia changed from "huge potential" to "reshape potential" in 2010, and changed again in 2012. For the "Huge Potential", 2015 to 2016 was the "Exploiting Potential" and 2017 was the "Huge Potential". In the past 10 years, the exports of 8 provinces and cities to Indonesia accounted for only 8 provinces and cities to the entire ASEAN exports. Around $7.23 \%$, the export potential of the 8 provinces and cities to Indonesia is fluctuating, and in 2017 it was "huge potential", indicating that in the future trade development, the 8 provinces and cities need to seize the opportunity to expand export trade. The Philippines in 2010 The "Huge Potential" has become a "Possible Remodeling", which has been maintained for 5 years and remained a "Potential Exploding Model" until 2015. It has remained a "Potential Developing Model" from 2015 to 2017. For 10 years, 8 provinces City exports to the Philippines accounted for 8About $.04 \%$, under the existing conditions, there is still a lot of room for improvement in the exports of the 8 provinces and cities to the Philippines. In 2010, Singapore 's export trade potential coefficient fluctuated significantly, changing from "huge potential" to "potential" "Development", the remaining years are "huge potential". In the past 10 years, the export trade between 8 provinces and cities and Singapore has continued to heat up. Among the 10 ASEAN countries, Singapore is the closest trade partner of 8 provinces and cities, so it is necessary to further expand the 8 provinces. The trade interaction between the city and Singapore needs to explore more favorable factors to stimulate bilateral trade. Thailand changed from a "high potential" to an " exploiting potential" in 2010, and then changed to a "high potential" in 2012. The remaining years Both are "high potential". The change from "high potential" to "potential development" indicates that Thailand's demand for commodities in 8 provinces and cities has decreased, and the volume of export trade has declined, and then it has become "high potential", indicating that 8 provinces The city 's export trade to Thailand is not vibrant enough, and like Singapore, it needs to find new favorable factors to stimulate the exports of 8 provinces and cities to Thailand. Brunei 's trade potential fluctuates greatly, from 2008 to 2011, it is in "potential reshaping", 2012 By 2016, it is a "large potential", and it will become ""Easy to reshape". The reason for the "reshape potential" from 2008 to 2011 was that before the establishment of the ASEAN Free Trade Area, the export volume of 8 provinces and cities to Brunei was extremely low, and after the establishment of the ASEAN Free Trade Area, 8 Provinces and cities' exports to Brunei increase, and the potential coefficient decreases. Brunei's change from "large potential" to "potential remodeling" in 2017 indicates that Brunei's demand for commodities in 8 provinces and cities has decreased, and the export trade volume has fallen. 8 provinces and cities need to improve the structure of export products and stimulate the demand of Brunei, so as to expand the export trade volume of 8 provinces and cities. Cambodia was a "potential development type" in 2009, 2012, 2014, 2016 and 2017, and the rest of the years as a "large potential", the trade potential coefficient fluctuates significantly. Like Singapore and Thailand, the 8 provinces and cities should actively use the new land and sea corridor to expand export trade, and at the same time adjust the supply structure to stimulate Cambodia's demand for exports from the 8 provinces and cities.

\section{In short}

Calculate the export trade volume of the 8 provinces and cities to the ten ASEAN countries from 2008 to 2017 by using the obtained gravity model. Compare the actual value with the theoretical prediction value to obtain the trade potential coefficient. According to Liu Qingfeng and Jiang Shuzhu (2002), The classification uses 1.2 and 
0.8 as the dividing line. When the ratio of theoretical value to actual value is greater than or equal to 1.2 , the trading partner country is a "potential remodeling"; when the ratio is between $0.8-1.2$, it is a "potential developing type"; when the ratio is less than 0.8 , it is "high potential".

\section{Acknowledgement}

The Fifth Batch of Excellent Talents Funding Program of Chongqing "Research on the Fusion Path of the Intersection of" Three Strategies "-Based on the Perspective of Strategic Behavior of Chongqing Inland Free Port, The phased results of the National Social Science Fund (2015XJL001), the "Research on the Impact of the New International Land and Sea Trade Channel on the Development of the Trade Potential of 9 Domestic Provinces and Cities" (No .: ZDB2018036), and the "Three Strategies" Meeting Point of the Chongqing Excellent Youth Project The phased results of "path research".

\section{References}

1. Jiang Guan, Huo Qiang. Trade Creation Effect and Trade Potential of China-ASEAN Free Trade Area-An Empirical Analysis Based on Panel Data of Gravity Model [j]. Time Finance, 2015 (2): 65

2. Nie Fei. Research on the Trade Creation Effect of China-ASEAN Free Trade Area Strategy [j]. Financial and Trade Research, 2017 (7): 41 